\title{
PENGARUH HARGA TERHADAP KEPUTUSAN PEMBELIAN KONSUMEN PD. KOPI KUDA BANDAR LAMPUNG
}

\author{
Andy Fitriyadi Dharmat Tilaar \\ Program Studi Manajemen, Sekolah Tinggi Ilmu Ekonomi Gentiaras, Bandar Lampung \\ Email : Ms006zeta2001@yahoo.com
}

\section{ABSTRACT}

Consumer perception of the same product or brand does not necessarily produce the same rating because not all consumers have complete knowledge of the condition of the product. Therefore, to be able to provide superior value to consumers and be able to calm competition, the company must know the consumer's judgment or perception of the competitor's product or brand, so that consumer preferences can be known for prices based on consumer perception.

In this research the consumer's decision to buy a product is based on the price. So from that price has a strong factor on the purchasing decision of a product. Related to this problem, it is necessary to study the variables that influence it so that efforts can be made to solve the problem of the low market share of coffee products from the PD Kopi Kuda. Then the research topic taken by researchers is: "The Influence of Prices on Consumer Purchasing Decisions PD. Kopi Kuda Bandar Lampung. "The research hypothesis is that there is an effect of Price $(X)$ on Purchasing Decisions $(Y)$ on Kopi Kuda products in Bandar Lampung. This type of research in this paper is an evaluation of Price $(X)$ on Purchase Decisions (Y) of Kopi Kuda Products

Discussion of the results of the analysis summary, the image can be interpreted that the price has a moderate influence of (62.2\%) on the decision to purchase Kopi Kuda products and is significant.

Keywords: Price, Purchasing Decision

\section{PENDAHULUAN}

\subsection{Latar Belakang}

Persaingan antara pasar industri kopi bubuk dan kopi instan semakin kompetetif. Hal ini terbukti dengan banyaknya jenis kopi instan yang beredar terutama produksi dalam negeri dari segala jenis merek. Membanjirnya produk kopi instan di pasaran mempengaruhi sikap seseorang terhadap pembelian dan pemakaian barang. Akan tetapi pemilihan produk kopi bubuk terlihat masih bertahan dan banyak dicari konsumen daripada kopi instan. Hal ini dikarenakan banyak orang yang ingin merasakan rasa original dari kopi tersebut. Kecintaan konsumen akan produk kopi bubuk membuat perusahaan pembuat kopi dapat bertahan di era modern yang serba instan. Pembelian suatu produk bukan lagi untuk memenuhi kebutuhan (need) melainkan karena keinginan (want). Sebagai perbandingan berikut ditampilkan hasil pendapat konsumen mengenai produk kopi PD Kopi Kuda dalam gambar sebagai berikut:

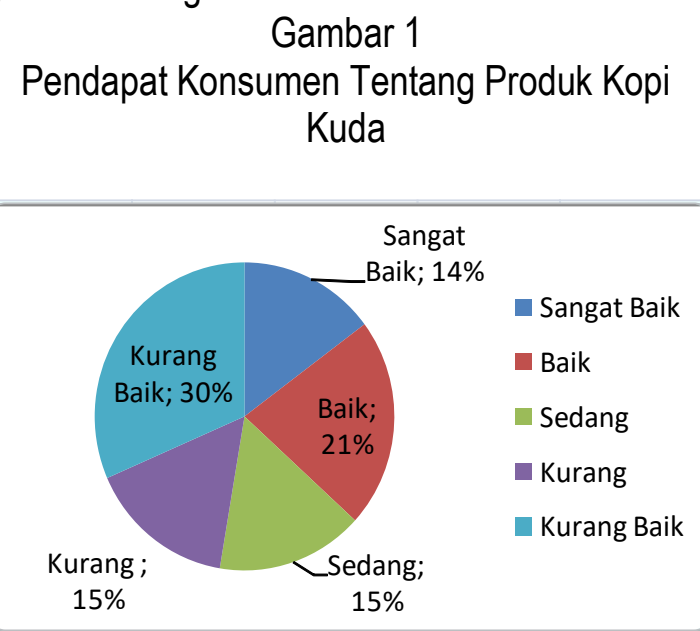

Sumber : PD Kopi Kuda, 2018

Berdasarkan gambar tersebut terlihat bahwa masih ada sebessar 30\% konsumen berpendapat kopi kuda belum dapat memberikan kepuasan pada konsumen. Sehingga dalam penelitian ini keputusan 
konsumen untuk membeli suatu produk didasari dengan adanya harga. Maka dari itu harga mempunyai faktor yang kuat terhadap keputusan pembelian suatu produk. Berdasarkan dari permasalahan yang muncul tadi, penurunan volume penjualan itu merupakan suatu pukulan keras bagi Perusahaan Daerah Kopi Kuda Bandar Lampung. Terkait dengan masalah tersebut maka perlu dipelajari variabel yang mempengaruhinya sehingga dapat dilakukan upaya untuk memecahkan masalah rendahnya pangsa pasar produk Kopi dari PD Kopi Kuda.

\subsection{Perumusan Masalah}

Bagaimana pengaruh harga terhadap keputusan pembelian konsumen PD. Kopi Kuda Bandar Lampung?"

\subsection{Tujuan Penelitian}

Penelitian ini bertujuan untuk menganalisis pengaruh harga terhadap keputusan pembelian konsumen PD. Kopi Kuda Bandar Lampung. Dengan manfaat penelitian yang akan dicapai adalah sebagai bahan pertimbangan obyektif pihak perusahaan untuk mewujudkan pengelolaan perusahaan yang lebih efektif dan sebagai masukan untuk membantu perusahaan dalam meningkatkan penjualan produknya khususnya pada penetapan harga.

\section{TINJAUAN PUSTAKA}

\subsection{Harga}

Sesuai dengan kerangka pemikiran dalam penulisan ini, maka variabel yang digunakan adalah variabel independen (variabel bebas) dan variabel dependent (variabel terikat). Sugiyono (2010), dalam penelitian ini, paradigma penelitian adalah merupakan pola pikir yang menunjukan hubungan antar variabel yang akan diteliti. Berdasarkan hal tersebut, maka penelitian yang merumuskan paradigma adalah penelitian yang bersifat asosiatif. Aspek-aspek teoritis yang akan dibahas diharapkan akan mendukung atau menjadi landasan dalam menelaah masalah penelitian yang telah dirumuskan, serta dapat memberikan dasar bagi peneliti dalam mengolah data, membahas hasil dan menarik kesimpulan penelitian.

Semakin banyaknya produsen yang terlibat dalam pemenuhan kebutuhan dan keinginan konsumen, menyebabkan setiap perusahaan harus dapat teliti dalam menetapkan harga. Menetapkan harga suatu produk tidaklah semudah yang kita bayangkan, ada beberapa proses yang harus dilakukan dalam penetapan harga suatu produk.

Menurut Basu Swasta (2011) Harga adalah sejumlah uang yang dibutuhkan untuk mendapatkan sejumlah kombinasi dari barang beserta pelayanannya. Valerie Zaithaml (2012) mengatakan bahwa menurut sudut pandang konsumen, harga adalah sesuatu sesuatu yang diberikan atau di korbankan untuk memperoleh suatu produk. Dalam menentukan harga terdapat strategi harga yang diartikan sebagai salah satu konten strategi pemasaran yang mengarah pada upaya pembentukan citra harga, daya saing harga, citra mutu,dan nilai pelanggan (Ferdinand,2007).

Menurut William J. Stanton (2008), harga adalah sejumlah nilai yang ditukarkan konsumen dengan manfaat dari memiliki atau menggunakan produk atau jasa yang lainnya ditetapkan oleh pembeli atau penjual untuk satu harga yang sama terhadap semua pembeli. Lilik Wahyudi (2006) menjadikan harga sebagai indikator berapa besar pengorbanan (sacrifice)yang diperlukan untuk membeli suatu produk sekaligus dijadikan sebagai indikator level of quality. Harga juga merupakan salah satu eleman bauran pemasaran yang paling fleksibel; harga dapat diubah dengan cepat, tidak seperti fitur produk dan perjanjian distribusi. Harga memiliki dua peranan utama dalam mempengaruhi keputusan pembelian, diantaranya :

1. Peranan alokasi dana, yaitu fungsi harga dalam membantu para pembeli untuk memutuskan cara memperoleh manfaat tertinggi yang diharapkan berdasarkan daya belinya dan berdasarkan biaya produksi.

2. Peranan informasi dari harga, yaitu fungsi harga dalam mendidik konsumen mengenai faktor-faktor produk, seperti kualitas. Hal ini terutama bermanfaat 
dalam situasi dimana pembeli mengalami kesulitan untuk menilai faktor produk atau manfaatnya secara obyektif, Secara kualitas produk

Faktor terpenting dari harga sebenarnya bukan harga itu sendiri akan tetapi harga subjektif, yaitu harga uang dipersepsikan oleh konsumen. Apabila konsumen mempresentasikan produk $A$ harganya tinggi atau mahal, maka hal ini akan berpengaruh positif terhadap "perceived quality dan perceived sacrifice" artinya konsumen mungkin memandang produk A adalah produk berkualitas. Oleh karena itu, wajar apabila memerlukan pengorbanan uang yang lebih mahal. Harga merupakan faktor penentu dalam pemilihan produk dan keputusan pembelian. Mengidentifikasikan harga sebagai salah satu faktor penting yang berpengaruh terhadap perilaku konsumen dalam kepuasan pembelian sehubungan dengan nilai dari produk atau jasa. Para konsumen tertarik untuk mendapatkan harga yang pantas. Harga yang pantas berarti nilai yang dipersepsikan pantas pada saat transaksi dilakukan.konsumen beranggapan bahwa suatu produk dengan harga yang yang mahal berarti mempunyai kualitas yang kurang baik. Sedangkan apabila harga yang murah mempunyai kualitas yang kurang baik. Dan diperkuat oleh penelitian yang dilakukan oleh Dodds (2010) menyatakan bahwa konsumen akan membeli suatu produk bermerek jika harganya di pandang layak oleh mereka.

Harga merupakan salah satu bagian yang sangatvpenting dalam pemasaran suatu produk karena harga adalah satu dari empat bauran pemasaran atau marketing mix (4P= product, price, place, promotion/produk, harga, distribusi, promosi). Harga adalah suatu nilai tukar dari produk barang maupun jasa yang dinyatakan dalam satuan moneter. Harga merupakan salah satu penentu keberhasilan suatu perusahaan karena harga menentukan seberapa besar keuntungan yang akan diperoleh perusahaan dari penjualan produknya baik berupa barang maupun jasa. Menetapkan harga terlalu tinggi akan menyebabkan penjualan akan menurun, namun jika harga terlalu rendah akan mengurangi keuntungan yang dapat diperoleh organisasi perusahaan.

Berdasarkan Teori Tersebut maka harga dalam penelitian ini didefinisikan dengan acuan teori dari Basu Swasta (2011) Harga adalah sejumlah uang yang dibutuhkan untuk mendapatkan sejumlah kombinasi dari barang beserta pelayanannya. Indikator penelitian yaitu biaya produksi dan kesesuaian kualitas

\subsection{Keputusan Pembelian}

Keputusan pembelian merupakan bagian dari komponen perilaku dalam sikap mengkonsumsi. Doods, Monroe dan Grewal, (2009) dalam Bernard (2010) menyatakan bahwa keputusan membeli di definisikan sebagai kemungkinan bila pembeli bermaksud untuk membeli produk. Keputusan pembelian merupakan perilaku konsumen yang menunjukkan sejauh mana komitmennya untuk melakukan pembelian.

Keputusan pembelian berbeda dengan minat beli,minat beli adalah tahap kecenderungan responden untuk bertindak sebelum keputusan pembeli benar-benar dilaksanakan.beberapa faktor yang membentuk minat beli konsumen yaitu :

1. sikap orang lain,sejauh mana sikap orang lain mengurangi alternatif yang disukai seseorang akan bergantung pada dua hal yaitu,intensitas negatif orang lain terhadap alternatif yang disukai konsumen dan motivasi konsumen untuk menuruti keinginan orang lain.

2. Faktor situasi yang tidak terantisipasi,faktor ini nantinya akan dapat mengubah pendirian konsumen dalam melakukan pembelian.hal tersebut tergantung dari pemikiran konsumen sendiri,apakah dia percaya diri dalam memutuskan akan membeli suatu barang atau tidak.

Menurut Keller (2011), keputusan pembelian konsumen adalah seberapa besar kemungkinan konsumen membeli suatu merek atau seberapa besar kemungkinan konsumen untuk berpindah dari satu merek ke merak lainnya.bila manfaat yang dirasakan lebih besar dibandingkan pengorbanan untuk mendapatkannya,maka dorangan untuk 
membelinya semakin tinggi. Perilaku pembelian konsumen sering kali diawali dan di pengaruhi oleh bayaknya rangsangan (setimuli) dari luar dirinya,baik berupa rangsangan pemasaran maupun rangsangan dari lingkungannya. Rangsangan tersebut kemudian diproses dalam diri sesuai dengan karakteristik pribadinya, sebelum akhirnya diambil keputusan pembelian. Kareteristik pribadi konsumen yang dipergunakan untuk merposes rangsangan tersebut sangan komplek dan salah satunya adalah motifasi untuk membeli. Dalam penelitian Samu dalam Herjanto (2009) menujukan bahwa salah satu indikator suatu produk perusahan sukses atau tidaknya dipasar adalah seberapa jauh tumbuh keputusan pembelian konsumen terhadap produk tersebut.

Ajai dan Googstein (2010) mengatakan jika kita ingin mempengaruhi seseorang, maka cara yang terbaik adalah mempelajari apa yang dipikirkannya, maka akan didapatkannya tidak haya sekedar informasi tentang orang itu dan bagaimana proses informasi itu dapat berjalan dan bagaimana memanfaatkannya. Hal ini yang dinamakan "The Buyin Process" (Proses pembelian).

Secara teori menurutnya proses pembelian meliputi 5 (lima) hal Ajai dan Googstein (2010):

1. Need (kebutuhan), proses pembelian berawal dari adanya kebutuhan tak harus dipenuhi atau kebutuhan yang muncul pada saat itu dan memotifasi untuk melakukan pembelian.

2. Recognition (Pengenalan), mengenali kebutuhan itu sendiri untuk dapat menetapkan sesuatu untuk memenuhinya.

3. Search (Pencarian), merupakan bagian aktif dalam pembelian yaitu mencari jalan untuk mengisi kebutuhan tersebut.

4. Evaluation (Evaluasi), suatu proses untuk mempelajari semua yang didapat selama proses pencarian dan mengembangkan beberapa pilihan.
5. Decision (Keputusan), langka terahir dari suatu proses pembelian untuk mengambil keputusan berdasarkan informasi yang di terima.

Keputusan Pembelian diperoleh dari suatu proses belaja dan proses pemikiran yang membentuk suatu persepsi.keputusan pembelian yang muncul menciptakan suatu motivasi yang terus terekam dalam benaknya, yang pada akhirnya ketika seorang konsumen harus memenuhi kebutuhan akan mengaktualisasikan apa yang ada di dalam benaknya itu. Meskipun merupakan pembelian yang belum tentu akan dilakukan pada masa mendatang namun pengukuran tehadap minat pembelian umumnya dilakukan guna memaksimumkan prediksi terhadap pembelian aktual itu sendiri (Kinnear dan Taylor 2009). Dalam penelitian ini keputusan pembelian disefinikan dengan acuan teori dari Bernard (2010) menyatakan bahwa keputusan membeli didefinisikan sebagai Perilaku konsumen yang menunjukkan sejauh mana komitmennya untuk melakukan pembelian. Dengan indikator keputusan pembelian: yakni need dan want.

\subsection{Kerangka Pikir dan Hipotesis}

Setelah konsep ditentukan maka kerangka teoritik penelitian ini dirumuskan dalam suatu gambar kerangka pikir agar dapat digunakan sebagai acuan.

Gambar di bawah menjelaskan jika harga ditetapkan maka keputusan pembelian akan mengalami perubahan. Hal ini dimaksudkan formulasi harga akan mengakibatkan keputusan pembelian yang unik pada produk Kopi Kuda di Bandar Lampung. Gambar tersebut digunakan juga untuk menyederhanakan model dan menentukan fokus penelitian guna membentuk hipotesis. Berdasarkan uraian pada kerangka teoritis di atas, dirumuskan hipotesisnya diduga terdapat pengaruh Harga terhadap keputusan pembelian produk PD Kopi Kuda di Bandar Lampung. 
Gambar 2. Kerangka teoritik penelitian

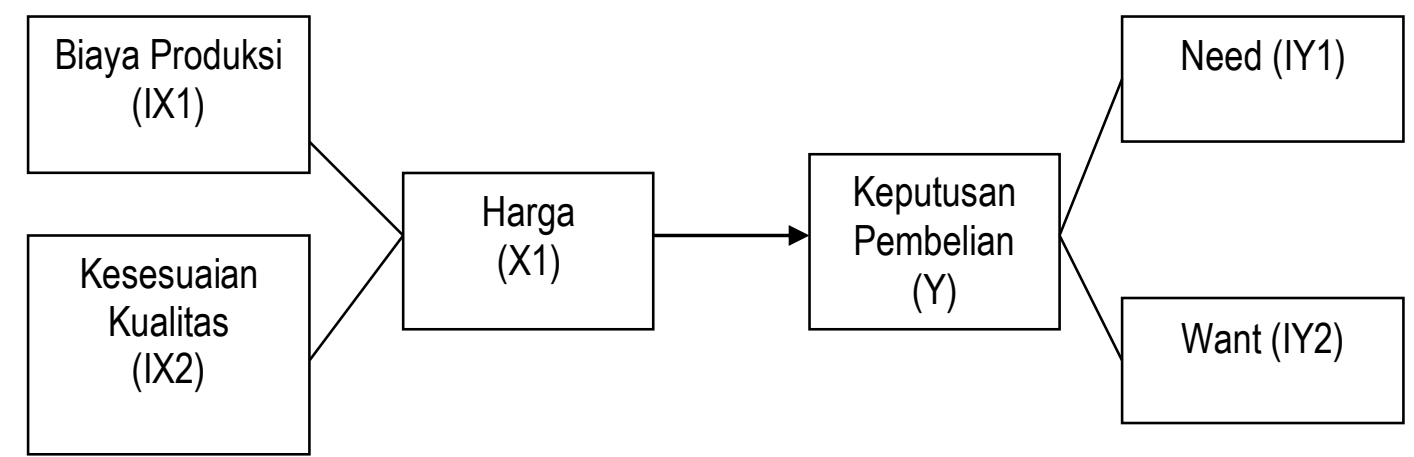

Sumber: Hubungan Konsep Penulis, 2018

\section{METODOLOGI PENELITIAN}

\subsection{Jenis Penelitian}

Jenis penelitian yang digunakan untuk penelitian ini adalah evaluasi tentang Harga ( $X$ ) terhadap Keputusan Pembelian (Y) Produk Kopi Kuda di Bandar Lampung. Dalam penelitian ini uji yang digunakan meliputi, uji reliabilitas, uji validitas, uji penyimpangan asumsi klasik, analisis regresi, uji signifikasi serta uji koefisien determinasi.

\subsection{Populasi dan Sampel}

Populasi yang diambil dalam penelitian ini adalah konsumen Kopi Kuda dengan jumlah yang tidak dibatasi. Berhubung jumlah populasi tidak diketahui maka penelitian menggunakan sampel snow ball dari populasi. Populasi yang akan diteliti oleh peneliti adalah konsumen Kopi Kuda secara kolektif dengan pengisian angket atau observasi, yaitu dengan mengambil sampel berdasarkan kegiatan dari cluster atau dalam kondisi normal dengan komposisi 30 responden percobaan dan responden pengambilan data primer dengan teknik snow ball.

\subsection{Teknik Pengumpulan Data}

Dimensi pengukuran Kinerja pada penelitian ini menggunakan pendapat menggunakan dimensi yang dikemukakan Danison (dalam Arikunto, 2012 : 135) dan disusun dalam bentuk skala Likert. Data yang diperlukan dalam penelitian ini meliputi Sugiono, (2010 : 230) Data Primer, yakni data yang diperoleh langsung melalui penelitian, baik melalui penggunaan kuesioner maupun wawancara. Data skunder, data yang diperoleh dari teknik dokumentasi dengan memanfaatkan sumber-sumber yang berkaitan dan dapat mendukung obyek yang akan diteliti.

Teknik pengumpulan data dalam penelitian ini adalah dengan; a) kuesioner yaitu daftar pertanyaan disebarkan secara tertutup dimana setiap pertanyaan sudah disediakan altenatif jawaban, sehingga responden hanya tinggal memilih salah satu alternatif jawaban yang dianggap sesuai kenyataan. b) Studi Kepustakaan dan Dokumentasi dilakukan dengan cara melihat dan mempelajari berbagai bahan bacaan, seperti buku-buku teoritis, makalah ilmiah, jurnal, dokumen dan laporanlaporan, temasuk barbagai peraturan yang berkaitan dengan variabel penelitian.

\subsection{Teknik Analisis Data}

\section{Uji Instrumen}

Dalam penelitian ini tinggi rendahnya validitas instrumen menunjukkan sejauh mana data yang terkumpul tidak menyimpang dari gambaran tentang validitas yang dimaksud dengan menggunakan korelasi product moment yang dikemukakan oleh Pearson dalam Arikunto, (2012: 220) Kesesuaian harga $r_{x y}$ diperoleh dari perhitungan dengan menggunakan rumus diatas dibandingkan dengan tabel harga regresi moment dengan korelasi harga $r_{x y}$ lebih besar atau sama dengan regresi tabel, maka butir instrumen tersebut valid dan jika $r_{x y}$ lebih kecil dari regresi tabel maka butir instrumen tersebut tidak valid. 
Reliabilitas adalah sesuatu instrumen cukup dapat dipercaya untuk digunakan sebagai alat pengumpul data karena instrumen tersebut sudah baik ( Arikunto, 2012 : 217). Pada penelitian ini untuk mencari reliabilitas instrumen menggunakan rumus alpha $\boldsymbol{\alpha}$, karena instrumen dalam penelitian ini berbentuk angket atau daftar pertanyaan yang skornya merupakan rentangan antara 1-5.

\section{Analisis Pembuktian Hipotesis}

Untuk analisis data dari responden yang diperoleh melalui kuesioner, digunakan analisis statistik. Analisis stasistik menurut Arikunto (2012 : 215) adalah yang digunakan seluruh rangkaian kerja suatu penelitian, diantaranya merumuskan hipotesis, menyusun instrumen peneltian, menentukan sampel, menganalisis data dan menarik suatu kesimpulan dari suatu penelitian. Berdasarkan hipotesis yang diajukan dalam penelitian ini, untuk mengetahui bentuk hubungan pengaruh antara variabel bebas ( $X$ ) terhadap variabel terikat $(Y)$ digunakan analisis statistik. Dalam hal ini $r$ YX merupakan koefisien korelasi pearson untuk uji validitas dan alpha pada reliabilitas. Struktur hubungan variabel tersebut dapat dinyatakan ke dalam persamaan regresi, yaitu : $\mathbf{Y}=\mathbf{b}_{0}+\mathbf{b}_{1} \mathbf{x}_{1}+\mathbf{b}_{2} \mathbf{x}_{2}$. Koefisien determinasi merupakan bagian dari keragaman total dari variabel tak bebas yang dapat diperhitungkan oleh keragaman variabel bebas dihitung dengan koefisien determinasi dengan asumsi dasar faktor-faktor lain di luar variabel dianggap tetap atau konstan. Untuk mengetahui nilai koefisien determinasi, maka dapat dihitung dengan menggunakan rumus (Sugiyono, 2010 : 165). KD $=r^{2} \times 100 \%$ Keterangan hasil korefisien: $\mathrm{KD}=0 \%$, berarti pengaruh (variabel $\mathrm{X}$ ) terhadap (variabel $\mathrm{Y}$ ). KD $=100 \%$, berarti pengaruh (variabel $X)$ terhadap (variabel Y).

Dalam penelitian ini juga diujikan beberapa uji yang bisanya tidak dilakukan sperti uji kontribusi indikator yang akan menggambarkan relefansi indikator trehadap pembentukkan variabel sehingga dapat dibentuk model penelitian yang lebih baik lagi

\section{HASIL PENELITIAN DAN PEMBAHASAN}

Hasil analisis data uji istrumen penelitian ini dirangkum dalam tabel berikut guna memudahkan peneliti dalam penggunaan alat analisis dengan responden percobaan sebesar 50 responden.

Tabel 1.

Rangkuman Hasil Uji Valid dan Reliablititas Seluruh Variabel

\begin{tabular}{ccccc}
\hline $\begin{array}{c}\text { Variabel / } \\
\text { Butir }\end{array}$ & $\begin{array}{c}\text { X1 } \\
\text { Harga }\end{array}$ & $\begin{array}{c}\text { Taraf } \\
\text { Signifikansi }\end{array}$ & $\begin{array}{c}\text { Y } \\
\text { Keputusan Pembelian }\end{array}$ & $\begin{array}{c}\text { Taraf } \\
\text { Signifikansi }\end{array}$ \\
\hline 1 & 0,736 & Valid & 0,435 & Tidak Valid \\
2 & 0,706 & Valid & 0,910 & Valid \\
3 & 0,727 & Valid & 0,813 & Valid \\
4 & 0,736 & Valid & 0,662 & Valid \\
5 & 0,824 & Valid & 0,890 & Valid \\
6 & 0,226 & Tidak Valid & 0,720 & Valid \\
\hline Reliabilitas & 0,869 & Reabel & 0,893 & Reabel \\
\hline
\end{tabular}

Sumber : Hasil rangkuman data olahan PASW, 2018

Berdasarkan tabel tersebut diketahui bahwa kuesioner atau instrumen penelitian telah siap dan dapat digunakan dalam melakukan pengambilan data guna mengungkap fenomena atau keadaan sesungguhnya yang hasilnya akan di jelaskan selanjutnya. Setelah uji Normalitas dan
Homogenitas pada responden penelitian sejumlah 150 responden penelitian terpenuhi maka data siap untuk dilakukan uji regresi berganda guna pembuktian hipotesis penelitian. Setelah dilakukan pengujian dan pembuktian hipotesis, selanjutnya dilakukan analisis untuk menguji hubungan indikator 
terhadap variabelnya dan dilakukan pada setiap variabel uji guna mendapatkan hasil yang lebih detail pada setiap variabelnya dengan menggunakan korelasi Pearson, Sekaran (2010).
Berikut ditampilkan hasil rata rata jumlah indikator pada variabel uji X1 Harga dan Keputusan Pembelian yang ditampilkan dalam tabel sebagai berikut:

Tabel 2.

Hasil Analisis Uji Indikator Pada Konsep

\begin{tabular}{llc}
\hline \multicolumn{1}{c}{ Variabel } & \multicolumn{1}{c}{ Indikator } & Rata-Rata \\
\hline \multirow{2}{*}{ Harga } & Biaya Produksi & 16,45 \\
& Kesesuaian Kualitas & 19,12 \\
\hline \multirow{2}{*}{ Keputusan Pembelian } & Need & 15,7 \\
& Want & 15,69 \\
\hline
\end{tabular}

Sumber Hasil Oleh Data Penelitian, 2018

Guna memudahkan interpretasi dari hasil regresi linier sederhana yang digabungkan dengan korelasi pada indikator terhadap variabel ujinya pada variabel - variabel yang mempengaruhi Keputusan Pembelian maka hasil analisis dirangkum dalam gambar rangkuman hasil uji yang ditampilkan sebagai berikut:

Gambar 3.

Rangkuman Hasil Analisis Penelitian

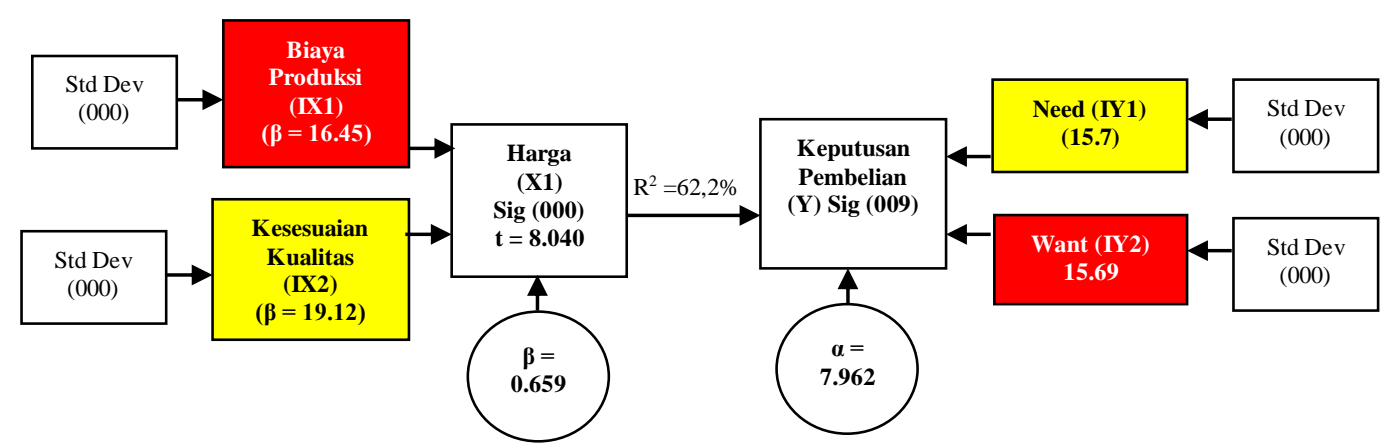

Sumber : Rangkuman Hasil Analisis PASW, 2018

Pembahasan dari hasil rangkuman analisis tersebut maka gambar tersebut dapat diinterpret

asikan bahwa Harga memiliki pengaruh yang sedang sebesar $(62,2 \%)$ terhadap Keputusan Pembelian produk kopi Kuda dengan kontribusi koefisien regresi sebesar 0.659 setiap terjadinya peningkatan harga terjadi. Pada variabel Harga juga didapatkan bahwa indikator IX12 yaitu Kesesuaian Kualitas memiliki kontribusi yang paling dominan dan Indikator IX11 Biaya Produksi memiliki kontribusi yang paling kecil. Kemudian Pada variabel Keputusan Pembelian indikator yang paling dominan membentuk variabel tersebut adalah IY1 yaitu Need dan indikator yang paling kecil dalam membentuk variabel Keputusan Pembelian adalah IY1 yaitu Want.

\section{SIMPULAN DAN SARAN}

\subsection{Simpulan}

Dari hasil analisis data dan pengujian hipotesis pengaruh harga terhadap keputusan pembelian Produk Kopi Kuda dapat diperoleh kesimpulan bahwa Harga memiliki pengaruh yang sedang sebesar $(62,2 \%)$ terhadap Keputusan Pembelian Produk Kopi Kuda dan siginifikan. Dari pengolahan data juga didapatkan bahwa masih ada variabel lain tetapi tidak begitu besar pengaruhnya yang 
belum dimasukkan tetapi memiliki pengaruh pada Keputusan Pembelian Produk Kopi Kuda sebesar $37,8 \%$.

\subsection{Saran}

Maka saran yang dapat diberikan bagi Perusahaan PD Kopi Kuda adalah pada variabel Harga saran yang dapat diberikan adalah meningkatkan kesesuaian kualitas dengan cara meningkatkan sistemproduksi agar dapat membuat kualitas kopi kuda menjadi lebih baik lagi dengan biaya yang lebih murah. Kemudian memperbaiki image kopi kuda karena dari hasil analisis diketahui bahwa konsumen kopi kuda menjadikan produk kopi pada kebutuhan yang sifatnya penting dan merupakan kebutuhan bukan keinginan ( Produk Essensial).

\section{DAFTAR PUSTAKA}

Arikunto, Suharsimi, (2012). Prosedur Penelitian-Suatu Pendekatan Praktek, Jakarta:Penerbit Bina Aksara

Bernand Foster, Timothy. 2007. 101 Cara Meningkatkan Kepuasan Pelanggan. Jakarta: Elex Media Komputindo

Doods Bell, Chip.R \& Bilijack.R.Bell. 2004. Magnetic Service: 7 Rahasia Menciptakan Pelanggan Setia. Bandung: Kaifa

Effendy, Ondang Uchyana, (2003). Pengantar Manajemen, Bandung: Penerbit Angkasa.
Ferdinand Nicole. 2009. How To Be Better At Customer Care. Jakarta: Elex Media Komputindo

George, D and Mallery, P. (2008). SPSS/PC Step by Step a Simple Guide and Reference. Belenot: Wods Worbb Publishing Company

Herjanto, Eddy (2009). Manajemen Produksi dan Operasi. Edisi 2 Jakarta Grasindo

Keller, 2011. (b) Manajemen Pemasaran Jilid II Edisi ke 11. Jakarta: PT. Indeks Kelompok Gramedia

Sugiyono. (2010). Statistika untuk Penelitian. Bandung. Alfabeta.

Swasta Basu 2011 Manajemen Penjualan (Edisi 3) BPFE Yogyakarta

Stanton, Terence A. 2009. Komunikasi Pemasaran Terpadu. Erlangga. Wasesa, Silih Agung. 2005

Sunarto. 2010. Prinsip-Prinsip Pemasaran 2. Yogyakarta: UST Peress

Suryabrata, S. 2010. Metodologi Penelitian. Jakarta: PT. Raja Grafindo Persada

Sutedja, Wira. 2007. Panduan Layanan Konsumen. Jakarta: Grasindo

Wahyudi. 2008. (b) Customer Relationship Management: Konsep dan Kasus. Jakarta: Harvarindo

Zeithalm Valarie A., A. Parasuraman 2004 Service Quality Marketing Science Institute New York 
ISSN 2086-9592 